\title{
小児悪性脳腫瘍の集学的治療
}

\author{
長嶋 達也 ${ }^{1)}$, 河村 淳史 ${ }^{1)}$, 山元 一樹1), 長嶋 宏明 ${ }^{2)}$ \\ 1）兵庫県立こぞも病院脳神経外科，2）神戸大学医学部脳神経外科
}

\section{Multidisciplinary Treatment of Malignant Pediatric Brain Tumors}

\author{
Tatsuya Nagashima, M.D., Ph.D. ${ }^{1)}$, Atsufumi Kawamura, M.D., Ph.D. ${ }^{1)}$, Kazuki Yamamoto, M.D. ${ }^{1)}$, \\ and Hiroaki Nagashima, M.D. ${ }^{2}$ \\ 1) Department of Neurosurgery, Kobe Children's Hospital, 2) Department of Neurosurgery, Kobe University School of Medicine
}

Brain tumors are the second most prevalent cancers in children (after leukemia) and remain the leading cause of cancer-related mortality in childhood. Treating children with brain tumors begins with an absolute requirement for the correct diagnosis, accurate staging of the extent of the disease and determination of the prognostic subgroup. Throughout treatment, every child with brain tumor should have the benefit of an expert pediatric cancer care team. The Japanese Ministry of Health, Labor and Welfare designated 15 hub hospitals to administer such comprehensive pediatric cancer care in 2013.

Medulloblastoma is the most common malignant childhood brain tumor. Overall survival rates for patients with medulloblastoma have reached $70-80 \%$ using treatment protocols that include a combination of surgery, cranio-spinal radiotherapy (in children $\geq 3$ years of age) and chemotherapy. Current risk stratification tools are solely based on clinical features, including age at diagnosis, extent of surgical resection, metastatic status. Molecular subclassification is rapidly informing the clinical management of medulloblastoma. These findings are currently making their way into risk-adapted treatment. Molecular characterization approaches have also yielded insights into new therapeutic targets.

Current management of ependymoma includes surgical resection followed by adjuvant radiotherapy. Children are especially difficult to manage because they often experience multiple recurrences. Numerous studies have shown that ependymoma is still a surgical disease. Recent advances in molecular studies have found that ependymomas have unique molecular signatures with distinct gene expression patterns, chromosomal changes, and protein expression. Through an improved understanding of the molecular and genetic basis of ependymoma, it is anticipated that patients will be risk-stratified and treated in the future.

The recent designation of pediatric cancer hub hospitals and molecular characterization approaches will hopefully lead to improved patient outcomes with reduced sequelae.

(Received Norvember 25, 2013 ; accepted December 10, 2013)

Key words : malignant brain tumor, pediatric brain tumor, multidisciplinary approach

Jpn J Neurosurg（Tokyo）23:409-417, 2014

\author{
はじめに \\ 小児脳腫瘍は白血病に次いで第 2 位の小児がんであ \\ り，小児期の悪性新生物による死亡の主たる原因となっ
}

\begin{abstract}
ている．ヒトゲノム計画による人間の全ゲノムの全塩基 配列の解明から 10 年を経て, 小児脳腫瘍の研究の発展

は “medulloblastomics”という言葉によって象徴的に表 される年分子的なサブグループ分類，リスク層別化，治
\end{abstract}

連絡先：長嶋達也， テ654-0081 神戸市須磨区高倉台 1-1-1 兵庫県立こども病院脳神経外科

Address reprint requests to: Tatsuya Nagashima, M.D., Ph.D., Department of Neurosurgery, Kobe Children's Hospital, 1-1-1 Takakuradai, Suma-ku, Kobe-shi, Hyogo 654-0081, Japan 
療強度の層別化が急速に展開しつつある.

小児がん治療の原則は, 正しい診断, 疾患の病期診断 と予後予測, 集学的治療, 晚期障害の予防である. また, すべての小児がん患児は特別な専門チームによる治療を 受ける必要があり, 根治する最大の好機は初期治療の期 間である.がん対策推進基本計画（2012 年）において, がんに対する医療政策の中に初めて小児がんも重点的に 取り組むべき課題として取り上げられたことにより，小 児がん拠点病院の整備が急速に進められている. 小児脳 腫瘍の集学的治療は単に手術, 化学療法, 放射線治療を 組み合わせた医療というのみならず，教育を含む療養環 境, 緩和医療, キャリーオーバー対応の整備も含めた包 括的な医療である。本稿では治療戦略が異なる髄芽腫と 上衣腫を例に挙げて述べる。

\section{髄芽腫}

化学療法, 放射線療法ともに感受性を有することから 集学的治療の対象となる代表的な脳腫瘍である。近年, 分子的サブグループ分類, 新しいリスク層別化による治 療, 分子標的薬の開発, がん幹細胞を対象とした治療な ぞが期待されている ${ }^{14)}$.

\section{1 標準的治療の成果と課題}

現在のリスク分類は, 診断時の年齢が 3 歳以下の乳幼 児, 残存腫瘍サイズ $1.5 \mathrm{~cm}^{2}$ 以上, 髄液播種性転移陽性例 はハイリスク群，それ以外は標準リスク群に層別化され ている. 1990〜2000 年代に 5 年生存率が 70\%を超えた 頃から ${ }^{16)}$, 晚期障害を意識して標準リスク群に対する治 療は全脳凊髄照射が $23.4 \mathrm{~Gy}$ へ隇量され，後頭蓋窩 32.4

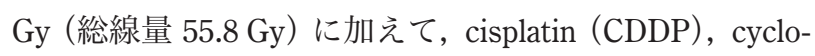
phosphamide (CPM), vincristine による化学療法を組み 合わせることにより (COG A9961, Phase III, Packer Regimen B), 5 年無事象生存期間 (event-free survival : EFS) $80 \%$ 以上が得られるようになった ${ }^{17)}$ 。これは「脳腫瘍取 り扱い規約第 3 版」にも ICE 療法とともに記載されてい $ろ^{13)}$.

腫瘍の全摘あるいは $1.5 \mathrm{~cm}^{2}$ 以下の残存腫瘍例の予後 が相対的によいことから, 可及的な全摘出が望ましい. 一方, 合併症を生じて化学放射線治療の開始が遅れるこ とは絶対に避けなければならない。頻度の高い（11〜 $29 \%)$ 合併症として小脳性無言症が知られている20) Fig.

1). 発症機序として両側 dentato-thalamo-cortical pathway の障害が指摘されており, 多くは可逆性と考えられ ていたが，言語機能などに永続的な障害を残す可能性が
あり避けなければならない合併症である。

生存率の向上とともに，小児がんを生き延びた患児た ち (cancer survivor) の多くが経験する，発達障害，内 分泌障害, 精神的社会的障害や二次がんなどの晚期障害 が問題となってきた（Fig. 2)．小児がん経験者の $62.3 \%$ が少なくとも一つの晚期合併症を，27.5\%が重篤なある いは生命に関わる晚期合併症を経験する ${ }^{15)}$. 脳腫瘍は複 数かつ重篤な晚期合併症をきたしやすいとされる．現在 の髄芽腫標準治療後（全脳脊䯣照射 $23.4 \mathrm{~Gy}$ ）の二次脳 腫瘍の 10 年累積発生率は $4.2 \%$ と推定されている ${ }^{18)}$.

\section{2 ハイリスク群に対する治療}

一方，ハイリスク群に対する標準的治療は確立されて いない. 3 歳以上のハイリスク群に対しては, 末梢血幹 細胞移植 (peripheral blood stem cell transplantation: PBSCT）を用いた大量化学療法を含む化学療法の強化, 十分な全脳脊䯣照射 $(36 \mathrm{~Gy})$, 脊髄転移部への追加照射 や髄腔内化学療法などさまざまな治療が試みられている ものの, 治療成績は十分ではな( ${ }^{316)} .3$ 歳未満の乳幼児 例は，放射線照射を 3 歳以降まで延期するのが基本であ るため治療はより困難であるが, 大量化学療法, 髄腔内 化学療法などの化学療法強化が一定の結果を出してい $ろ^{25)}$.

\section{3 髄芽腫の組織学的・分子的多様性と予後}

髄芽腫は多様な臨床像や治療反応性を規定するさまざ まな遺伝子異常を有する悪性腫瘍の不均一な集合体であ り，多様な画像所見，局在を示す. 2007 年の WHO 分類 で 4 亜型が分類された。組織亜型と予後には関係があ り, desmoplastic nodular medulloblastoma は 5 年生存率 $80 \%$ 以上, classic medulloblastoma は 60〜70\%, large cell/anaplastic (LC/A) medulloblastoma は 40〜50\%とさ れる1).

2012 年, 髄芽腫は異なつた遺伝子異常を持つ 4 つの基 本的なサブグループからなるというコンセンサスが得ら れた (Fig. 3 $)^{31)}$. すなわち, (1)WNT シグナル伝達系の異 常に基づく群，(2)SHH（sonic hedgehog）シグナル伝達 系の異常に基づく群, (3)シグナル伝達系異常の詳細が不 明な group 3, group 4 である. WNT (Wingless) サブグ ループは, 核内 $\beta$-catenin の免疫組織学的染色強陽性を 特徴とし，5 年生存率は $90 \%$ を超える予後良好なサブグ ループである. Group 3 は, myelocytomatosis oncogene (MYC) 増幅に特徴づけられ, 乳幼児に多く, LC/A medulloblastoma の大部分を占めており, 5 年生存率は $30 \%$ と 予後は最も悪い. 

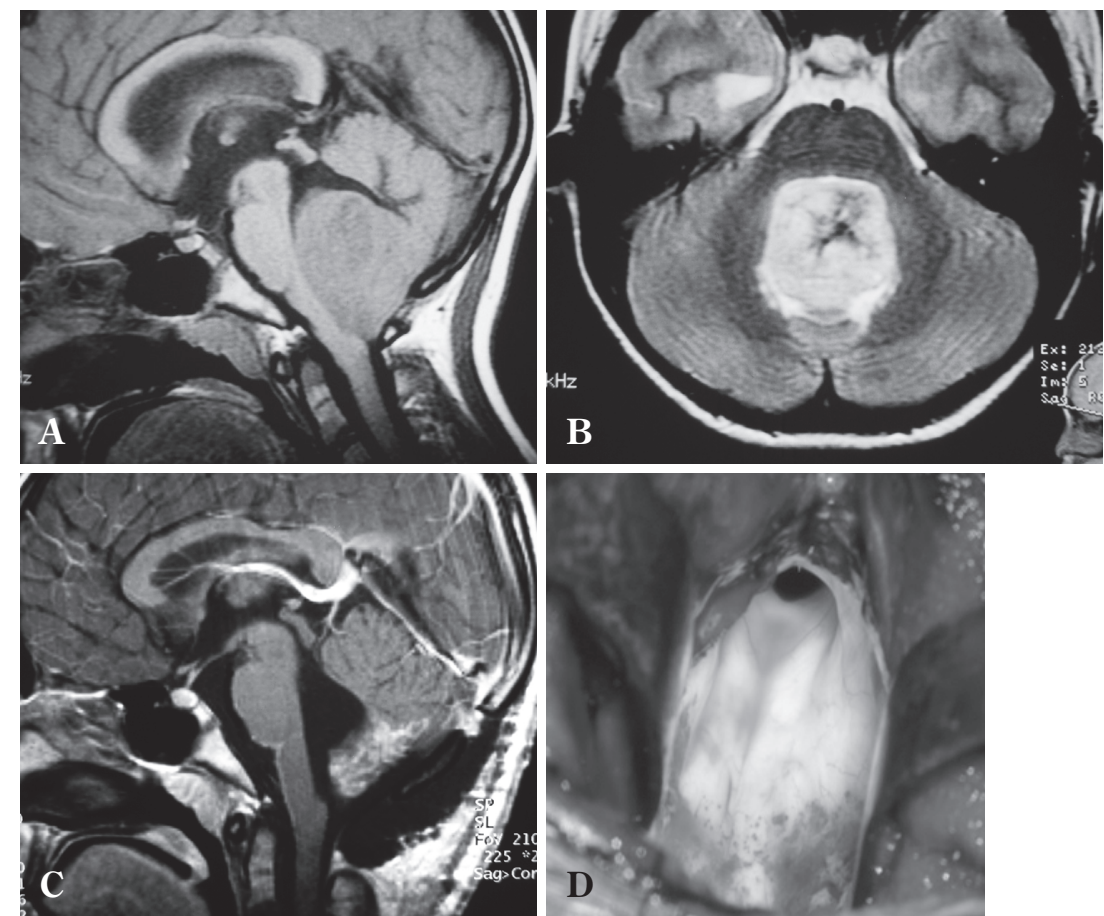

Fig. 1 Total resection of medulloblastoma

A : Preoperative sagittal MRI with $\mathrm{T} 1$-weighted image.

B : Preoperative axial MRI with T2-weighted image.

C : Postoperative sagittal MRI with T1-weighted image.

D : Intraoperative photograph after total resection of the tumor. The cerebral aqueduct and the fourth ventricle floor are identified.

\section{4 治療の基本戦略}

\section{1. 新しいリスク層別化}

組織学的, 分子・細胞遺伝学的診断により予後因子と 治療層別診断を行い，治療強度を個別化していくという 癌治療の基本戦略に従う。迅速で再現性があり, コスト・ パフォーマンスに優れた国際標準となり得るリスク層別 化法の確立が課題である。分子的サブグループと組織亜 型・予後との関係は, 年齢の要素も加わつて複雑である. 重要なことは, WNT サブグループは予後良好であるこ と, LC/A medulloblastomaは組織型単独で予後不良因子 となり得ることである.

Ellison $ら^{2)}$ は，播種の有無と formalin-fixed paraffinembedded（FFPE）組織を用いて免疫組織学的な $\beta$-catenin 核陽性の有無, interphase fluorescene in situ hybridization (iFISH) による MYC 増幅の有無からリスク分類を 行った. 5 年生存率は, low risk 群 (13\%) で $90 \%$ 以上, 標準リスク群 (59\%) で約 70\%, high risk 群 (28\%) で 約 45\%であった. Schwalbe ら ${ }^{26)}$ は DNA methylation profile を解析し, MXI1 と IL8 の methylation をリスクファ クターに加えて重みづけを行うことにより 3 層のリス ク分類がより精密になるとした (Fig. 4)。5 年生存率は

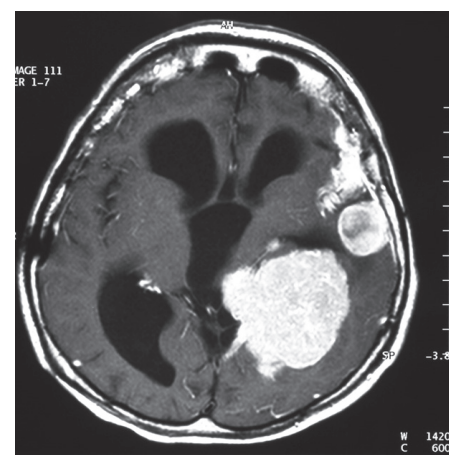

Fig. 2 MRI with $\mathrm{Gd}-$ enhanced T1-weighted image of a radiation induced late onset multiple meningioma in a 20 -year-old patient. The patient underwent medulloblastoma resection and whole craniospinal radiation of $35 \mathrm{~Gy}$ at 7 months old and suffered severe psychomotor retardation.

low risk 群（46\%）で 90\%以上，high risk 群（16\%）で $20 \%$ 強であった，層別化の基準により，low risk 群の占 める割合が $13 \%$ から $46 \%{ }^{26)}$ に大きく変化することは, 今後臨床研究をデザインするうえで再現性のある層別化 法の確立が重要であることを示している. 


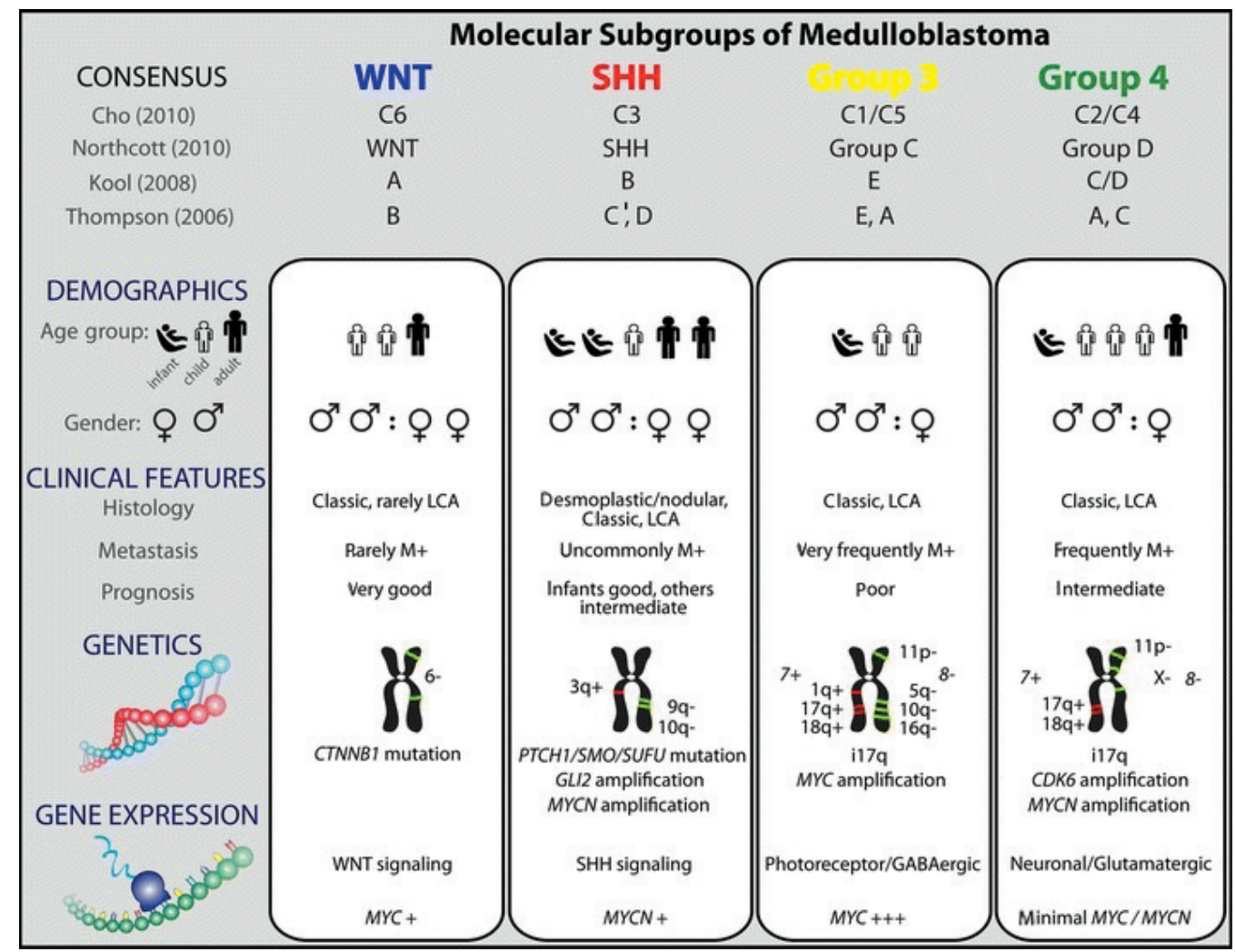

Fig. 3 Comparison of the various medulloblastoma subgroups including their affiliations with previously published papers on medulloblastoma molecular subgrouping (Reproduced from Ref. 31)

\section{2. 今後の研究課題}

晚期障害軽減の観点に基づき，low risk 群に対する治 療軽減が課題である。治療軽減の一つとして全脳脊髄照 射線量の減量があるが, わが国の標準的治療法はすでに $24 \mathrm{~Gy}$ を選択しており, さらなる減量（例えば 18 Gy） の可能性については新たな臨床研究を要する.

一方, 予後がきわめて不良な high risk 群の治療強化も 問題となる。現在すでに大量化学療法を治療プロトコー ルに組み込んでいる場合は, 治療強度は限界に達してお り強化の余地は少ない. 髄腔内化学療法の強化や維持化 学療法の工夫が一つの選択肢になる. 分子標的薬や ${ }^{9) 22)}$, 腫瘍幹細胞を標的とした治療戦略のブレイクスルーが期 待される ${ }^{29)}$.

3 歳未満の乳幼児例は一律にハイリスク群と評価され るが，この年齢群におけるリスク層別化治療も問題であ $3^{7) 24)}$. 発生頻度が低いため臨床研究に乗りにくいこと もあり，新しいリスク分類は 3 歳未満の乳幼児を対象と していない. 乳幼児髄芽腫に対する治療戦略として, (1) 末梢血幹細胞移植を用いた大量化学療法 ${ }^{3)}$, (2)全身およ び脳室内の methotrexate 投与療法 ${ }^{24)}$, (3)全身化学療法
と comformal radiotheropy（CMRT）の組み合わせなどが 試みられている. Rutkowski ら ${ }^{24)}$ は, 3 歳未満例に対して 髄腔内 methotrexate 投与を用いた化学療法のみによる 治療を試み, 転移のない例では 5 年無増悪生存期間 (progression-free survival : PFS), 全生存期間 (overall survival：OS)がそれぞれ 68\%,78\%であり,20/30 例 (66\%) で放射線照射を回避できたとしている。 Desmoplastic histology，全摘，転移なし，2 歳未満が，独立した予後 良好因子であったとしている。乳幼児例も治療反応性が 異なった多様な群からなっていることが明らかになるに したがって，分子的なサブグループ分類を 3 歳未満群に 当てはめ得るのかどうか，特に放射線照射を避け得るサ ブグループを抽出できるかというのは切実な問題であ る.

\section{上衣腫}

上衣腫は星細胞腫，髄芽腫に次ぐ発生率第 3 位の小児 脳腫瘍であり, 半数は 5 歳以下, 3 分の 1 は 3 歳未満に 発生する。長期予後は標準リスクの髄芽腫より悪い. 上 

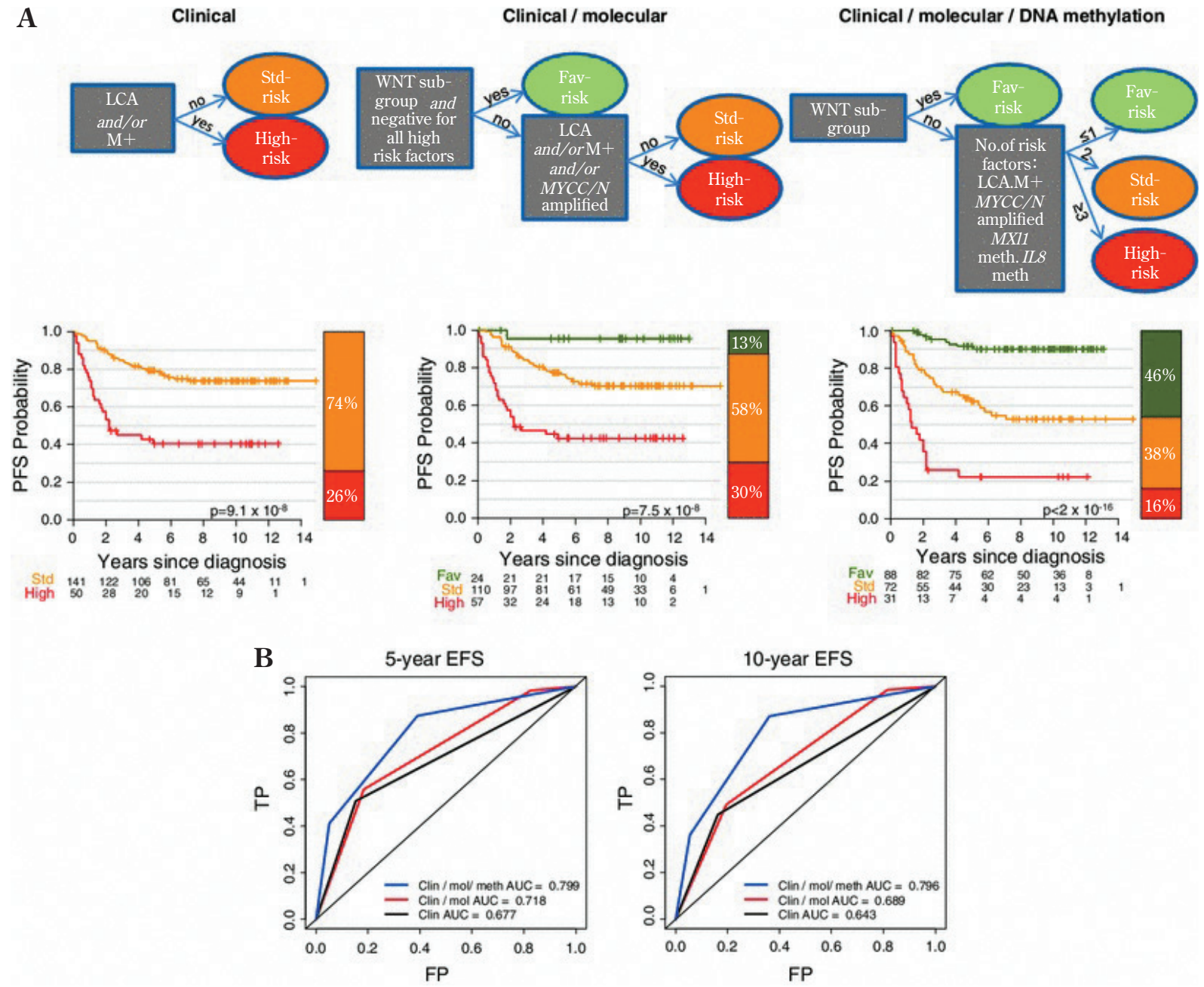

Fig. 4 Risk stratification using DNA methylation markers in 191 medulloblastoma patients aged 3.0-16.0 at diagnosis

A : Current clinical (upper left panel) and clinical/molecular (upper middle panel) models were assessed alongside a novel model incorporating DNA methylation biomarkers (upper right panel), and used to derive Kaplan-Meier plots (lower). LCA: large-cell/anaplastic pathology, M+: metastatic disease, MXI1 and IL8 meth, methylated $(\beta \geqq 0.67)$. Low risk green, standard risk amber, high risk red. $\mathrm{p}$ values from Log-rank tests are shown.

B : Time-dependent ROC curves for all three models at 5 and 10 years. The area under the curve (AUC) is shown for each model. FP: false positive rate, TP: true positive rate, Fav: favorable, Std: standard (Reproduced from Ref. 27 with permission)

衣腫は基本的に局所腫瘍であることから，集学的治療に おける外科的治療の比重が高い「脳外科医の腫瘍」であ る.

\section{1 標準的治療の到達点と課題}

現時点における標準的治療は，可及的全摘と放射線治 療である。発症時に $90 \%$ は局所発生であり, 予防的な全 脳脊髄照射は行わない。 また, 3 歳未満は放射線照射を 避けるのが原則である。化学療法を併用することは多く の施設で試みられているが，標準となり得る成績を示し
得たプロトコールはない，標準治療の代表的な成績とし て，5 年 PFS，5 年 OS それぞれ $50 \%$ と $64 \%$ が報告され ている ${ }^{21)}$. 全摘出の可否が予後を最も左右し, 10 年 OS とPFS は全摘例で $69.8 \%$ と $57 \%$, 残存例で $32.5 \%$ と $11 \%$ であり ${ }^{19)}$ ，長期の治療成績は満足し得るものではな い.

\section{2 外科的治療}

手術の原則は可及的全摘出である。全摘が望ましいと はいうものの，一般に初回手術における全摘率は $42.2 \%$ 


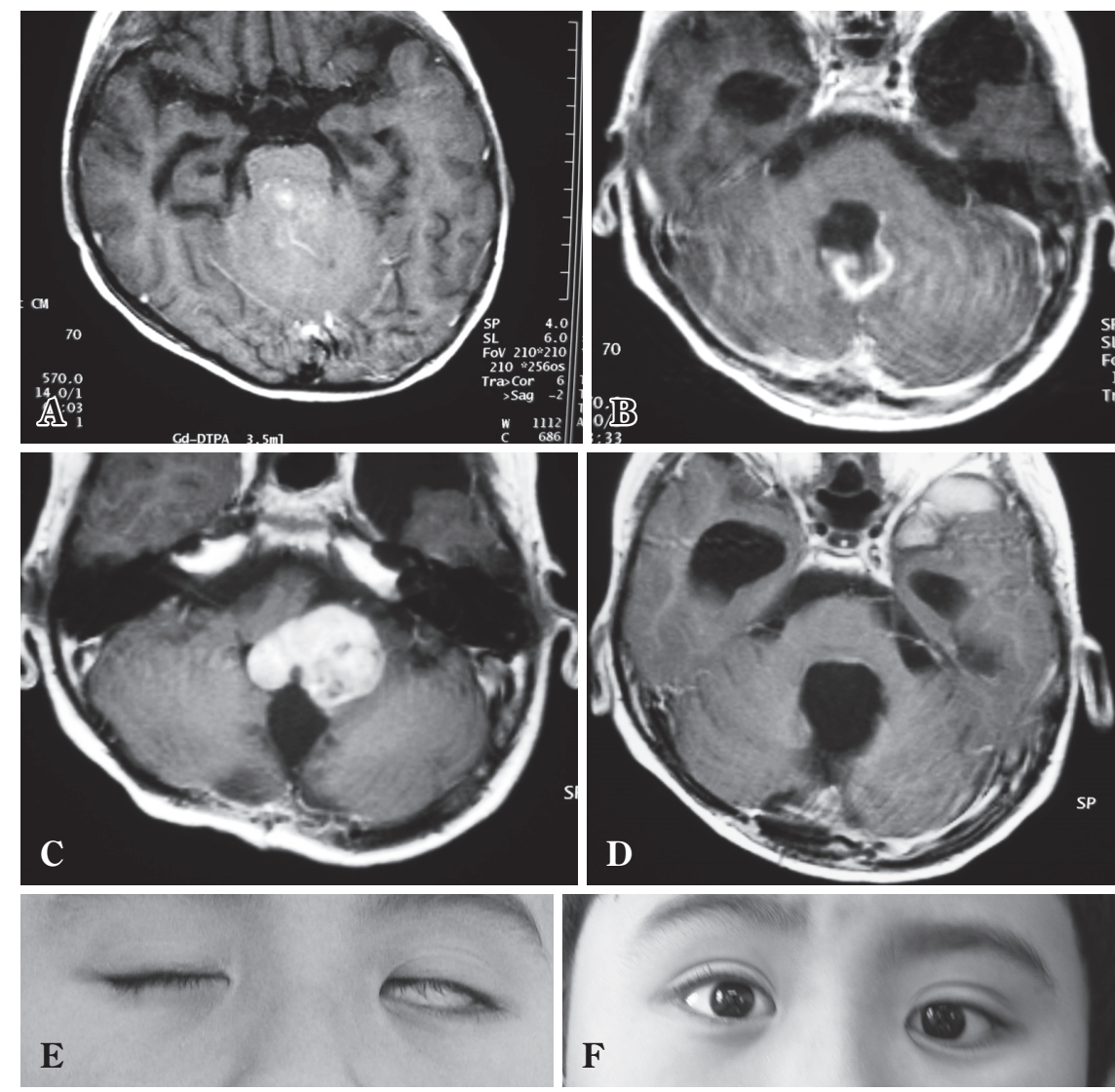

Fig. 5 Total resection of recurrent ependymoma

A : Preoperative MRI with $\mathrm{Gd}^{-}$enhanced $\mathrm{TI}$-weighted image at the first operation.

B : Preoperative MRI with $\mathrm{Gd}^{-}$enhanced TI-weighted image at the first operation.

C : MRI with $\mathrm{Gd}$-enhance T1-weighted image, 3 years after the first operation. A recurrent tumor was located at the primary tumor site.

D : Total removal of the recurrent tumor.

E, F : The patient showed moderate left facial and abducens nerve palsy after the operation.

に留まる ${ }^{30)}$ ，手術経験の差に影響を受けやすい腫瘍であ り，実績のある術者に委ねることが望ましい，術直後に MRI を撮影し残存があれば “second-look surgery”をす る可能性についても最初から両親に説明しておかなけれ ばならない。

予後は腫瘍局在に強く関係しており，特に第四脳室外 側部に発生した腫瘍は予後不良である ${ }^{5)}$. 積極的な second-look surgery により $81.7 \%$ という高い全摘率も報告 されている ${ }^{12)}$ ，再手術時の全摘出が大きなリスクなしで 行えるとしている論文もあるが10)，筆者の経験では，第 四脳室底の上衣層ごと剝離する困難な手術といわざるを 得ない（Fig. 5)。2 回目の手術における全摘率が grade II で 66\%, grade IIIでは 0\%であることから, 初回手術 で全摘出可能であった low grade 腫瘍が再手術のよい対 象になるとする報告もあるが30)，一方，grade と全摘率 は無関係であるとの報告もある ${ }^{12}$.

再発腫瘍の摘出は小さいほど全摘も定位的放射線治療 もしやすい. 早期発見のための脳 MRI は, 最初の 1 年は 3 カ月ごと, 5 年までは 6 カ月ごと, それ以降は 1 年ご とに行い, 脊髄 MRI は症状がないかぎり年 1 回として いる.

\section{3 放射線治療}

術後放射線照射は標準であるが，全摘後の放射線照射 の要否については天幕上下で意見が異なる，天幕下上衣 腫では, 肉眼的全摘されていても放射線照射を加えるこ とによる生存率向上が示されている ${ }^{23)}$. 天幕上の上衣腫 については，全摘後に放射線照射を回避できる可能性が 
指摘されており ${ }^{8)}$, 放射線照射を避け得るサブグループ を選択することが課題である。

再発腫瘍に対する定位的放射線治療（stereotactic radiotherapy：SRT）の効果について, 26 例を治療して 3 年 PFS が $66 \%$ という良好な報告があり, 複数回の SRT も可能なことから, 全摘出困難な再発上衣腫に対す る治療選択肢として重要である ${ }^{28)}$. Merchant ${ }^{12)}$ は小児 上衣腫例を高い全摘率とCMRT によって治療し, 7 年 EFS と OS が $69.1 \%$ と $81.0 \%$ という良好な成績を報告 している. 粒子線治療は, 正常脳への被曝を低減できる という生物学的性質を有するために小児への効果が期待 されてきた. 小児 70 例（平均年齢 38 力月）を治療し平 均 46 力月の経過観察で 3 年 PFS $76 \%$, OS 95\%の報告 があり, 今後の発展が期待される ${ }^{27)}$.

\section{4 化学療法}

上衣腫に対する標準的化学療法は確立していない. $\mathrm{UKCCSG} / \mathrm{SIOP}$ では 3 歳以下の上衣腫 89 例に対する放 射線照射を避けて先行化学療法を行い, 非播種例 80 例 のうち $42 \%$ で 5 年間照射を避け得たとされる ${ }^{4)}$. 一方, “Head Start III” 研究における 19 例の経験では, 天幕上 上衣腫では引き続き検討する価値を認めたが，天幕下上 衣腫では否定的な結果が得られており ${ }^{32)}$, 化学療法の評 価は一定しない。放射線治療にも限界があり, 分子標的 薬剤や腫瘍幹細胞を標的にした治療法などの新しい治療 法が最も求められる腫瘍である ${ }^{11)}$.

\section{5 分子的サブグループ分類とリスク層別化治療}

遺伝子発現のプロファイル分析から上衣腫が 3 つの 基本的なサブグループ，すなわち(1)天幕上型，(2)後頭蓋 窩型，(3)後頭蓋窩・脊髄型からなることが示された ${ }^{33)}$. 組織学的には同じにみえる後頭蓋窩上衣腫には臨床的, 分子的に異なった 2 つのサブタイプが存在し, LAMA2 と NELL2 の免疫組織染色で分類できる. Group A は, 若 年層の外側に発生し, 再発や二次的播種が多く, 5 年 PFS，OS が 47\%，69\% と予後不良な一群である. Group B は, 年長者の正中に発生し, 5 年 PFS, OS が $79 \%, 95 \%$ と予後は良好である。

放射線治療の効果が相対的であること, 有効な化学療 法がないことからリスク層別化治療は髄芽腫に比して困 難なものとなることは避けられない. 今後, 新しい分子 的サブグループ分類に基づいてリスク層別化した治療の 方向の中で, 全摘された低リスク群の天幕上上衣腫の中 から放射線照射を回避できるサブグループ，ハイリスク 群の中から大量化学療法併用などの治療強化や 3 歳未
満に対する放射線照射などで生存率が向上するサブグ ループの抽出なども課題となる。

\section{政策としての小児がん医療}

わが国の対がん政策は, 2004 年に策定された「第 3 次 対がん 10 か年総合戦略」に基づき進められてきた. 2007 年に施行された「がん対策基本法」と「がん対策推進基 本計画」から 5 年が経過し, がん診療連携拠点病院の整 備などの成果を得た。一方，小児においてもがんは病死 原因の第 1 位であるにもかかわらず，その対策は積み残 されてきた。わが国では 200 を超える施設で小児がん診 療が行われているが，欧米先進国では小児がん治療を行 う施設については施設およびマンパワーに高い必要要件 が定められており, 結果的に集約化が進んでいる.

2012 年から 5 年間の「がん対策推進基本計画」におい て，重点的に取り組むべき課題として新たに「小児への がん対策の充実」が定められた。 小児がんの治療は，手 術, 化学療法, 放射線治療の組み合わせとしての集学的 治療の枠を越えて, 晚期障害への対処, 緩和医療, 家族 サポート，キャリーオーバーへの取り組みなど，施設・ マンパワーの両面から包括的な医療システムを必要とす ることが政策課題として明確にされた。2013 年 2 月に 15 施設が指定された小児がん拠点病院では, 欧米先進国 の小児がん治療センターの要件に匹敵する人的・施設的 要件を満たすことが求められている．小児がん治療がわ が国の政策課題となった機会に，小児脳腫瘍に対する治 療も集約化し, 脳神経外科, 小览腫瘍科, 放射線科, 病 理, 基礎研究者からなる全国的な臨床研究として進める 体制整備が急務である。

\section{文 献}

1) Ellison DW, Dalton J, Kocak M, Nicholson SL, Fraga C, Neale G, Kenney AM, Brat DJ, Perry A, Yong WH, Taylor RE, Bailey S, Clifford SC, Gilbertson RJ: Medulloblastoma : clinicopathological correlates of SHH, WNT, and non-SHH/WNT molecular subgroups. Acta Neuropathol 121: 381-396, 2011.

2) Ellison DW, Kocak M, Dalton J, Megahed H, Lusher ME, Ryan SL, Zhao W, Nicholson SL, Taylor RE, Bailey S, Clifford SC: Definition of disease-risk stratification groups in childhood medulloblastoma using combined clinical, pathologic, and molecular variables. J Clin Oncol 29: 1400-1407, 2011.

3) Gajjar A, Chintagumpala M, Ashley D, Kellie S, Kun LE, Merchant TE, Woo S, Wheeler G, Ahern V, Krasin MJ, Fouladi M, Broniscer A, Krance R, Hale GA, Stewart CF, Dauser R, Sanford RA, Fuller C, Lau C, Boyett JM, Wallace D, Gilbertson RJ: Risk-adapted craniospinal radio- 
therapy followed by high-dose chemotherapy and stemcell rescue in children with newly diagnosed medulloblastoma (St Jude Medulloblastoma-96) : long-term results from a prospective, multicentre trial. Lancet Oncol 7 : 813-820, 2006.

4) Grundy RG, Wilne SA, Weston CL, Robinson K, Lashford LS, Ironside J, Cox T, Chong WK, Campbell RH, Bailey CC, Gattamaneni R, Picton S, Thorpe N, Mallucci C, English MW, Punt JA, Walker DA, Ellison DW, Machin D, Children's Cancer and Leukaemia Group (formerly UKCCSG) Brain Tumour Committee : Primary postoperative chemotherapy without radiotherapy for intracranial ependymoma in children: the UKCCSG/SIOP prospective study. Lancet Oncol $\quad$ 8: 696-705, 2007.

5) Ikezaki K, Matsushima T, Inoue T, Yokoyama N, Kaneko Y, Fukui $\mathrm{M}$ : Correlation of microanatomical localization with postoperative survival in posterior fossa ependymomas. Neurosurgery $32:$ 38-44, 1993.

6) Jakacki RI: Treatment strategies for high-risk medulloblastoma and supratentorial primitive neuroectodermal tumors. Review of the literature. J Neurosurg 102 (1 Suppl) : 44-52, 2005.

7) Johnston DL, Keene D, Bartels U, Carret AS, Crooks B, Eisenstat DD, Fryer C, Lafay-Cousin L, Larouche V, Moghrabi A, Wilson B, Zelcer S, Silva M, Brossard J, Bouffet $\mathrm{E}$ : Medulloblastoma in children under the age of three years: a retrospective Canadian review. I Neurooncol 94: 51-56, 2009.

8) Kumar R, Singhal N, Jaiswal SK, Mahapatra AK : Recurrence in supratentorial anaplastic ependymoma. Pediatr Neurosurg 43:364-368, 2007.

9) Metcalfe C, Alicke B, Crow A, Lamoureux M, Dijkgraaf GJ, Peale F, Gould SE, de Sauvage FJ : PTEN loss mitigates the response of medulloblastoma to Hedgehog pathway inhibition. Cancer Res 73: 7034-7042, 2013.

10) Massimino M, Solero CL, Garrè ML, Biassoni V, Cama A, Genitori L, Di Rocco C, Sardi I, Viscardi E, Modena P, Potepan P, Barra S, Scarzello G, Galassi E, Giangaspero F, Antonelli M, Gandola L: Second-look surgery for ependymoma: the Italian experience. J Neurosurg Pediatr 8: 246-250, 2011.

11) Mack SC, Witt H, Wang $X$, Milde $T$, Yao Y, Bertrand KC, Korshunov A, Pfister SM, Taylor MD : Emerging insights into the ependymoma epigenome. Brain Pathol $23: 206^{-}$ 209, 2013

12) Merchant TE, Li C, Xiong X, Kun LE, Boop FA, Sanford $\mathrm{RA}$ : Conformal radiotherapy after surgery for paediatric ependymoma : a prospective study. Lancet Oncol 10: 258-266, 2009.

13）日本脳神経外科学会，日本病理学会編：Medulloblastoma 髄芽腫. 臨床・病理 脳腫瘍取扱い規約一臨床と病理力 ラーアトラス。東京，金原出版，2010，pp.255-258.

14) Northcott PA, Jones DT, Kool M, Robinson GW, Gilbertson RJ, Cho YJ, Pomeroy SL, Korshunov A, Lichter P, Taylor MD, Pfister SM: Medulloblastomics: the end of the beginning. Nat Rev Cancer 12:818-834, 2012.

15) Oeffinger KC, Mertens AC, Sklar CA, Kawashima T, Hudson MM, Meadows AT, Friedman DL, Marina N, Hobbie W, Kadan-Lottick NS, Schwartz CL, Leisenring W, Robison LL, Childhood Cancer Survivor Study: Chronic health conditions in adult survivors of childhood cancer. $N$ Engl $J$ Med 355 : 1572-1582, 2006.
16) Packer RJ, Sutton LN, Elterman R, Lange B, Goldwein J, Nicholson HS, Mulne L, Boyett J, D’Angio G, WechslerJentzsch K, Reaman G, Cohen BH, Bruce DA, Rorke LB, Molloy P, Ryan J, LaFond D, Evans AE, Schut L: Outcome for children with medulloblastoma treated with radiation and cisplatin, CCNU, and vincristine chemotherapy. $J$ Neurosurg 81: 690-698, 1994.

17) Packer RJ, Gajjar A, Vezina G, Rorke-Adams L, Burger PC, Robertson PL, Bayer L, LaFond D, Donahue BR, Marymont MH, Muraszko K, Langston J, Sposto R: Phase III study of craniospinal radiation therapy followed by adjuvant chemotherapy for newly diagnosed averagerisk medulloblastoma. J Clin Oncol 24: 4202-4208, 2006.

18) Packer RJ, Zhou T, Holmes E, Vezina G, Gajjar A: Survival and secondary tumors in children with medulloblastoma receiving radiotherapy and adjuvant chemotherapy: results of Children's Oncology Group trial A9961. Neuro Oncol 15: 97-103, 2013.

19) Perilongo G, Massimino M, Sotti G, Belfontali T, Masiero L, Rigobello L, Garrè L, Carli M, Lombardi F, Solero C, Sainati L, Canale V, del Prever AB, Giangaspero F, Andreussi L, Mazza C, Madon E: Analyses of prognostic factors in a retrospective review of 92 children with ependymoma: Italian Pediatric Neuro-oncology Group. Med Pediatr Oncol 29: 79-85, 1997.

20) Robertson PL, Muraszko KM, Holmes EJ, Sposto R, Packer RJ, Gajjar A, Dias MS, Allen JC, Children's Oncology Group: Incidence and severity of postoperative cerebellar mutism syndrome in children with medulloblastoma: a prospective study by the Children's Oncology Group. J Neurosurg 105 (6 Suppl) : 444-451, 2006.

21) Robertson PL, Zeltzer PM, Boyett JM, Rorke LB, Allen JC, Geyer JR, Stanley P, Li H, Albright AL, McGuire-Cullen P, Finlay JL, Stevens KR Jr, Milstein JM, Packer RJ, Wisoff $\mathrm{J}$ : Survival and prognostic factors following radiation therapy and chemotherapy for ependymomas in children: a report of the Children's Cancer Group. J Neurosurg 88:695-703, 1998.

22) Robinson G, Parker M, Kranenburg TA, Lu C, Chen X, Ding L, Phoenix TN, Hedlund E, Wei L, Zhu X, Chalhoub N, Baker SJ, Huether R, Kriwacki R, Curley N, Thiruvenkatam R, Wang J, Wu G, Rusch M, Hong X, Becksfort J, Gupta P, Ma J, Easton J, Vadodaria B, Onar-Thomas A, Lin T, Li S, Pounds S, Paugh S, Zhao D, Kawauchi D, Roussel MF, Finkelstein D, Ellison DW, Lau CC, Bouffet E, Hassall T, Gururangan S, Cohn R, Fulton RS, Fulton LL, Dooling DJ, Ochoa K, Gajjar A, Mardis ER, Wilson RK, Downing JR, Zhang J, Gilbertson RJ: Novel mutations target distinct subgroups of medulloblastoma Nature 488: 43-48, 2012.

23) Rogers L, Pueschel J, Spetzler R, Shapiro W, Coons S, Thomas T, Speiser B: Is gross-total resection sufficient treatment for posterior fossa ependymomas? J Neurosurg 102:629-636, 2005.

24) Rutkowski S, Bode U, Deinlein F, Ottensmeier H, Warmuth-Metz M, Soerensen N, Graf N, Emser A, Pietsch T, Wolff JE, Kortmann RD, Kuehl J : Treatment of early childhood medulloblastoma by postoperative chemotherapy alone. N Engl J Med 352: 978-986, 2005.

25) Rutkowski S, von Hoff K, Emser A, Zwiener I, Pietsch T, Figarella-Branger D, Giangaspero F, Ellison DW, Garre ML, Biassoni V, Grundy RG, Finlay JL, Dhall G, Raquin 
MA, Grill J : Survival and prognostic factors of early childhood medulloblastoma: an international meta-analysis $J$ Clin Oncol 28: 4961-4968, 2010.

26) Schwalbe EC, Williamson D, Lindsey JC, Hamilton D, Ryan SL, Megahed H, Garami M, Hauser P, DembowskaBaginska B, Perek D, Northcott PA, Taylor MD, Taylor RE, Ellison DW, Bailey S, Clifford SC: DNA methylation profiling of medulloblastoma allows robust subclassification and improved outcome prediction using formalinfixed biopsies. Acta Neuropathol 125: 359-371, 2013.

27) Macdonald SM, Sethi R, Lavally B, Yeap BY, Marcus KJ, Caruso P, Pulsifer M, Huang M, Ebb D, Tarbell NJ, Yock TI : Proton radiotherapy for pediatric central nervous system ependymoma: clinical outcomes for 70 patients. Neuro Oncol 15: 1552-1559, 2013.

28) Stauder MC, Ni Laack N, Ahmed KA, Link MJ, Schomberg PJ, Pollock BE: Stereotactic radiosurgery for patients with recurrent intracranial ependymomas. J Neurooncol 108: 507-512, 2012.

29) Sugihara E, Saya $\mathrm{H}$ : Complexity of cancer stem cells. Int J Cancer 132: 1249-1259, 2013.

30) Tamburrini G, D’Ercole M, Pettorini BL, Caldarelli M, Massimi L, Di Rocco C: Survival following treatment for intracranial ependymoma: a review. Childs Nerv Syst
25: 1303-1312, 2009.

31) Taylor MD, Northcott PA, Korshunov A, Remke M, Cho YJ, Clifford SC, Eberhart CG, Parsons DW, Rutkowski S, Gajjar A, Ellison DW, Lichter P, Gilbertson RJ, Pomeroy SL, Kool M, Pfister SM : Molecular subgroups of medulloblastoma: the current consensus. Acta Neuropathol 123: 465-472, 2012.

32) Venkatramani R, Ji L, Lasky J, Haley K, Judkins A, Zhou S, Sposto R, Olshefski R, Garvin J, Tekautz T, Kennedy G, Rassekh SR, Moore T, Gardner S, Allen J, Shore R, Moertel C, Atlas M, Dhall G, Finlay J: Outcome of infants and young children with newly diagnosed ependymoma treated on the "Head Start" III prospective clinical trial. $J$ Neurooncol 113: 285-291, 2013.

33) Witt H, Mack SC, Ryzhova M, Bender S, Sill M, Isserlin R, Benner A, Hielscher T, Milde T, Remke M, Jones DT, Northcott PA, Garzia L, Bertrand KC, Wittmann A, Yao Y, Roberts SS, Massimi L, Van Meter T, Weiss WA, Gupta N, Grajkowska W, Lach B, Cho YJ, von Deimling A, Kulozik AE, Witt O, Bader GD, Hawkins CE, Tabori U, Guha A, Rutka JT, Lichter P, Korshunov A, Taylor MD, Pfister SM : Delineation of two clinically and molecularly distinct subgroups of posterior fossa ependymoma. Cancer Cell 20: 143-157, 2011.

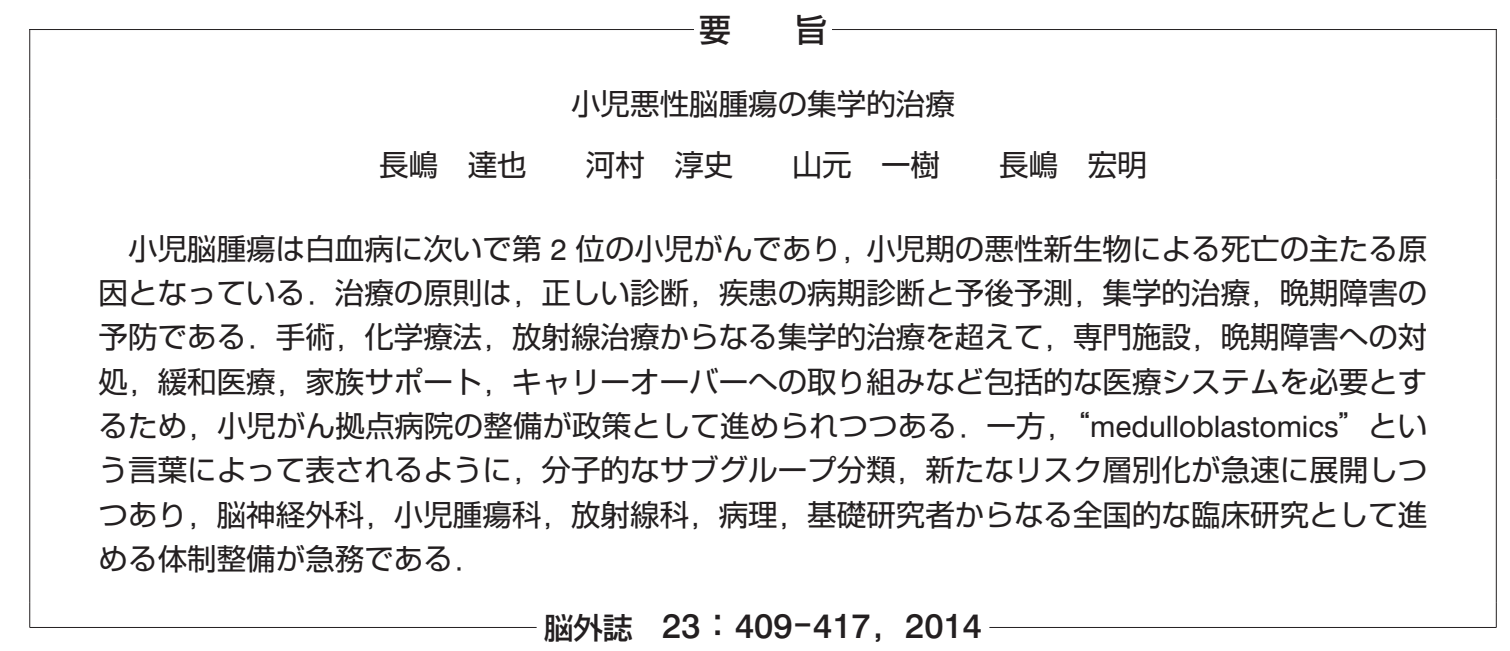

